\title{
The Effect of Carbon Sources on the Thermal Shock Properties of MgO-C Refractories
}

\author{
Tuba Bahtli ${ }^{1, *}$, Veysel Murat Bostanci ${ }^{2}$, Derya Yesim Hopa ${ }^{3}$, Serife Yalcin Yasti ${ }^{4}$ \\ ${ }^{1}$ Department of Metallurgy and Materials Engineering, Faculty of Engineering and Architecture, \\ Necmettin Erbakan University, Konya, Turkey \\ ${ }^{2}$ Department of Mechanical Engineering, Institute of Science and Technology, Necmettin Erbakan University, Konya, Turkey \\ ${ }^{3}$ Department of Chemical Engineering, Faculty of Engineering, Afyon Kocatepe University, Afyonkarahisar, Turkey \\ ${ }^{4}$ Department of Ceramic, Fine Arts Faculty, Selcuk University, Turkey
}

Copyright $\subseteq 2018$ by authors, all rights reserved. Authors agree that this article remains permanently open access under the terms of the Creative Commons Attribution License 4.0 International License

\begin{abstract}
Thermal shock resistance of MgO-C refractories, which were used in the iron and steel industry, by incorporation of pyrolytic carbon black obtained by waste tire pyrolysis was investigated. The effect of porosity on the thermal shock resistance of those refractories as a function of carbon source (graphite or pyrolytic carbon black) was also examined in the current study. The microstructure and fracture surfaces were characterized using the Scanning Electron Microscopy (SEM). Experimental studies showed that refractories produced by the use of pyrolytic carbon black had higher amount of porosity and lower thermal shock resistance than refractories containing flake graphite.
\end{abstract}

Keywords Pyrolysis, Carbon Black, Waste Tire, MgO-C refractories, Thermal Shock

\section{Introduction}

Refractories are materials that are resistant to high temperature, and used as furnace linings for elevated temperature materials processing [1]. Although refractories are used in the glass melting, cement, and ceramic industries, the greatest user is the iron and steel industry [1].

The MgO-C (magnesia-carbon) bricks are widely used in the steel industry, electric arc furnaces, and basic furnaces because of its excellent resistance to erosion, corrosion and thermal shock, and hot strength [2-4].

Generally, carbon refractories contain a high amount of carbon content up to $12-20 \mathrm{wt} \%$, and the main carbon source is flaky graphite due to its non-wetting nature and anisotropic properties, excellent corrosion resistance from molten metal and slag attack $[4,5]$. The smaller the graphite flake size, the higher the strength of the body due to the smaller defect size. Bending strength increases with increasing the graphite content in a carbon-bonded system [1].

However, the mechanical and thermal properties of the $\mathrm{MgO}^{-} \mathrm{C}$ are deteriorated due to the spalling and pore generation by the oxidiation of graphite. Therefore, antioxidants are added into the $\mathrm{MgO}-\mathrm{C}$ batches during fabrication in order to improve high temperature behavior and oxidation resistance [6]. Thus, various additives such as $\mathrm{Si}, \mathrm{Al}, \mathrm{SiC}, \mathrm{MgAl}_{2} \mathrm{O}_{4}, \mathrm{TiO}_{2}$, and $\mathrm{B}_{4} \mathrm{C}$ powders are incorporated into $\mathrm{MgO}-\mathrm{C}$ bricks to improve their resistance to oxidation. Among these additives, Si powder is the most important and widely used one [7].

In carbon-bonded oxide refractories, the aggregate phases, typically $\mathrm{MgO}$, are held together by a complicated bond system derived from decomposition of tar/pitch or phenolic resin binders [1]. The phenolic resin phase remains as a three-dimensional network containing the refractory ingredients and imparts cold strength to the refractory body. This also reduces the elastic modulus of the refractory which is required for better thermal shock resistance [4].

Thermal shock can be defined as serious cracking in components subject to rapid changes in temperature. Carbon-bonded oxides have good thermal shock resistance due to the high thermal conductivity of carbon leading to reduced thermal gradients and a microstructure which is resistant to crack propagation [1].

Mechanical and thermal properties of $\mathrm{MgO}-\mathrm{C}$ determined at room temperature emphasize that:

- these properties are mainly governed by the carbonaceous materials at room temperature

- the carbon content presents in both the binder and the graphite and contributes to achieve a higher resistance to initiation of cracks due to thermal shock.

- higher content of graphite presents greater deformation at the fracture level. 
- $\quad$ higher porosity and a higher percentage of sintered magnesia with the quality of the binder could reduce the firebrick's fracture strength at room temperature [8].

Waste tires are increasingly becoming an important environmental problem. The current main routes for the management of waste tires are energy recovery, material recycling, retreading, and export. Pyrolysis is an alternative method with the possibility for the recovery of valuable products from used tires [9]. The pyrolysis or thermal degradation under inert conditions of waste tyres gives away to three main products; gases, tyre pyrolysis oil (TPO), and residual pyrolysis char [10]. The inorganic components (mainly steel) and mineral fillers remain as relatively unaltered solid residues which are referred as Pyrolytic Carbon Black [11].

In the present study, thermal shock resistance of $\mathrm{MgO}-\mathrm{C}$ refractories produced by either flake graphite or pyrolytic carbon black obtained from the waste tire pyrolysis and used as carbon sources for $\mathrm{MgO}-\mathrm{C}$ refractories were investigated as a function of their porosities and densities.

\section{Materials and Methods}

In this study, commercially fused Magnesia and flake graphite were used as a raw materials. Also, the other raw material used as a carbon source for magnesia-carbon (MgO-C) refractories was pyrolytic carbon black.

Pyrolytic carbon black was produced by pyrolysis of waste tire at $500^{\circ} \mathrm{C}$ with $15^{\circ} \mathrm{C} / \mathrm{min}$ heating rate and 0.5 litre/min $\mathrm{N}_{2}$ flow rate. The particle size of waste tire was between about $70 \mu \mathrm{m}$ and $850 \mu \mathrm{m}$. After pyrolysis, that solid product was extracted twice by $37 \% \mathrm{HCl}$ and $65 \%$ $\mathrm{HNO}_{3}$ acid mixtures with $1: 1$ volume percentage at $175^{\circ} \mathrm{C}$ in order to provide sulphur removal. After these steps, the carbon black was extracted by $1 \mathrm{~N} \mathrm{H}_{2} \mathrm{SO}_{4}$ and $10 \mathrm{~N} \mathrm{NaOH}$ solutions at $60^{\circ} \mathrm{C}$ with $1: 1$ volume percentage in order to decrease the ash content. After the improvement, the amount of sulphur was reduced from 8.16 to 2.02 and the amount of ash decreased from 0.64 to 0.49 .

Phenolic resin as binder, antioxidant, Novalac, and Hexamine were also used in refractory prescriptions given in Table 1. Either $50 \mathrm{~mm} \times 50 \mathrm{~mm} \times 50 \mathrm{~mm}$ (width $\times$ length $\times$ height) square prism samples or $25 \mathrm{~mm} \times 25 \mathrm{~mm} \times 150 \mathrm{~mm}$ (width $\times$ thickness $\times$ length) in the form of bar samples were shaped by applying pressure of $100 \mathrm{MPa}$. The shaped samples were tempered in Nabertherm N11/R ash furnace at $250{ }^{\circ} \mathrm{C}$ for 3 hours with of $5^{\circ} \mathrm{C} / \mathrm{min}$ heating rate.

The amount of porosity in a material affects the mechanical properties as strength and elasticity, thermal properties, and corrosion resistance. Porosity and density measurements were based on the Archimedes principle in the current study.

For the thermal shock tests, five pieces for each composition produced in the forms of either $50 \mathrm{~mm} \times 50 \mathrm{~mm} \times 50 \mathrm{~mm}$ or $25 \mathrm{~mm} \times 25 \mathrm{~mm} \times 150 \mathrm{~mm}$ square prisms were used. Before the test, those samples were put into chamotte refractory container in order to prevent oxidation and closed with graphite. Then they were heated up to $1000^{\circ} \mathrm{C}$ with $10^{\circ} \mathrm{C} / \mathrm{min}$ heating rate in Nabertherm $\mathrm{N} 11 / \mathrm{R}$ ash furnace and held at $1000^{\circ} \mathrm{C}$ for 10 minutes, thrown into cold water, and quenched.

Before and after the thermal shock test at $1000{ }^{\circ} \mathrm{C}$ :

i) Cold crushing strength (CCS) test was applied to five pieces of $50 \mathrm{~mm} \times 50 \mathrm{~mm} \times 50 \mathrm{~mm}$ square prism samples for each material by Liya compression testing machine. 200-ton loads were applied with $4 \mathrm{kN} / \mathrm{sec}$ rate, and $\mathrm{CCS}(\mathrm{MPa})$ was calculated by dividing the load $(\mathrm{N})$ by the cross-sectional area $\left(\mathrm{mm}^{2}\right)$.

ii) 3-point bending test was performed on five pieces of $25 \mathrm{~mm} \times 25 \mathrm{~mm} \times 150 \mathrm{~mm}$ bar samples by Shimadzu AGS-X device according to ASTM C1161-90, L=125 $\mathrm{mm}$ and the loading speed was set to be $0,15 \mathrm{MPa} / \mathrm{s}$. The 3-point bending strength and elastic modulus were determined using the following equations where $\mathrm{P}$ is the fracture load $(\mathrm{N}), \mathrm{L}$ is the distance between supports $(\mathrm{m}), \mathrm{W}$ is the width of the sample $(\mathrm{m}), \mathrm{D}$ is the thickness of the sample $(\mathrm{m})$, and $\mathrm{m}$ is the slope of the stress-strain $(\sigma-\mathrm{E})$ curve $(\mathrm{N} / \mathrm{m})[12]$ :

$$
\begin{gathered}
\text { Strength: } \sigma=\frac{3}{2} * \frac{P . L}{W D^{2}} \\
\text { Elastic Modulus: } E=\frac{L^{3}}{4 * W^{*} D^{3}} * m
\end{gathered}
$$

Table 1. Prescriptions of $\mathrm{MgO}-\mathrm{C}$ refractories

\begin{tabular}{cccccc}
\hline Composition & $1-4 \mathrm{~mm} \mathrm{MgO}(\%)$ & $\begin{array}{c}0-1 \mathrm{~mm} \mathrm{MgO} \\
(\%)\end{array}$ & $\begin{array}{c}\text { Powder }(<63 \mu) \mathrm{MgO} \\
(\%)\end{array}$ & $\begin{array}{c}\text { Flake Graphite } \\
(\%)\end{array}$ & $\begin{array}{c}\text { Pyolkic } \\
\text { Carbon } \\
\text { Black (\%) }\end{array}$ \\
\hline C1 & 50 & 30 & 10 & 10 & 0 \\
\hline C2 & 50 & 30 & 10 & 0 & 10 \\
\hline C3 & 50 & 30 & 10 & 6.66 & 3.33 \\
\hline
\end{tabular}


Then the strength ratio values for each material which means the percentage of retained strength were calculated by dividing the strengths after the thermal shock test by the strengths before thermal shock test.

In order to examine the microstructure by the Scanning Electron Microscopy (SEM), the samples were cut into $20 \mathrm{~mm} \times 20 \mathrm{~mm} \times 20 \mathrm{~mm}$ for each refractory composition given in Table 1 with the MAC Allister ceramic cutting device. The cut samples were cold molded. $20 \mathrm{ml}$ of polyester were mixed with $1 \mathrm{ml}$ of curing agent for a minute, then $1 \mathrm{ml}$ of accelerator was added, and the mixture was stirred for another minute. The resin was poured onto the sample in a mold and cold molded for 30 minutes. Then samples were polished with Metkon polishing machine using $150,300,600$, and 1200 grits for five minutes, respectively.

Characterization microstructures of those polished samples were performed by the SEM-Mapping analysis with backscattered electron images at 1000x magnification. Also, elemental analysis of those refractories was examined by Energy Dispersive X-Ray Analysis (EDX).

For fracture surface characterization before and after thermal shock, the $25 \mathrm{~mm} \times 25 \mathrm{~mm} \times 150 \mathrm{~mm}$ bar samples subjected to 3-point bending test were cut and cold molded as mentioned above. Fracture surfaces of samples were characterized by the SEM with secondary electron images at $1000 \mathrm{x}$ magnification.

\section{Results and Discussion}

\subsection{Porosities and Densities of MgO-C Refractories}

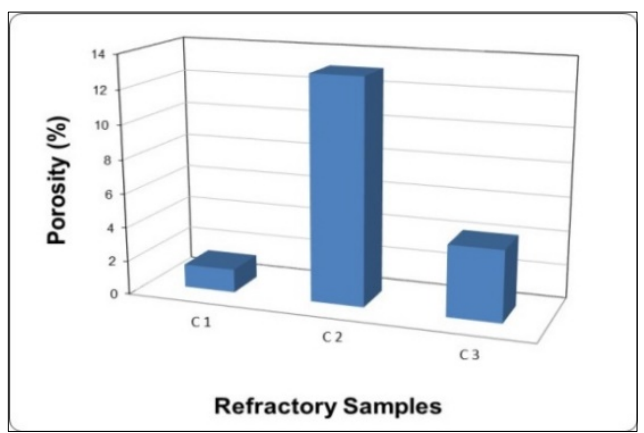

(a)

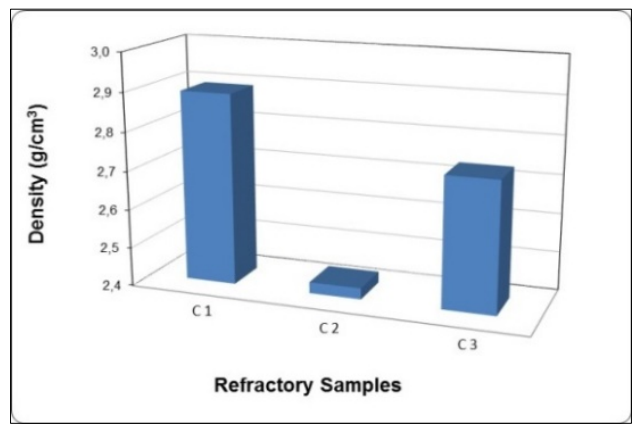

(b)

Figure 1. a) Porosity and b) density values of $\mathrm{MgO}-\mathrm{C}$ refractories
The density and porosity graphs of $\mathrm{MgO}-\mathrm{C}$ refractories produced by incorporation of graphite and pyrolytic carbon black are given in Figure 1.

As the amount of porosity in those $\mathrm{MgO}-\mathrm{C}$ refractories decreased, the density values increased. The $\mathrm{C} 1$ sample obtained with graphite and phenolic resin had the highest density value. The increase in the amount of pyrolytic carbon black reduced the density values of the produced compositions. The lowest density and the highest porosity were observed in the $\mathrm{C} 2$ composition produced by only pyrolytic carbon black as a carbon source.

\subsection{Mechanical Behaviours of MgO-C Refractories before Thermal Shock Test}

The Cold Crushing Strength (CCS) graphs for the square prism shaped compositions are given in Figure 2.

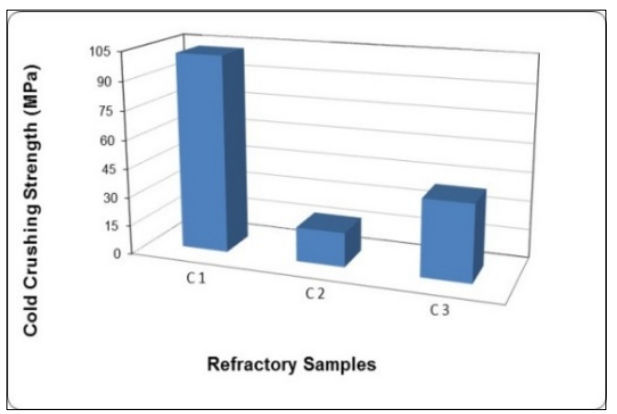

Figure 2. Cold Crushing Strength (CCS) for $\mathrm{MgO}-\mathrm{C}$ refractories before thermal shock test

It was observed that the higher strength values of $\mathrm{C} 1$ composition were produced by incorporation of graphite and phenolic resin. When the CCS values were compared, the CCS value decreased as the amount of pyrolytic solids increased and graphite decreased. Increasing the density value and decreasing the porosity value caused an increase in the CCS, and thus it was observed that the porosity had a negative effect on the CCS.

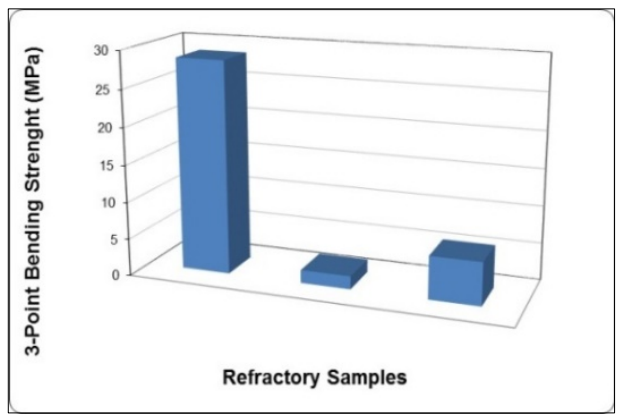

Figure 3. 3-point bending strength values of $\mathrm{MgO}-\mathrm{C}$ refarctories

The 3-point bending strength graphs for the bar shaped compositions are given in Figure 3.

Similar results were obtained with CCS. While the bending strength of $\mathrm{K} 1$ composition produced with resin and graphite admixtures had the highest bending strength 
value as similar to the $\mathrm{CCS}$ value, 3-point bending strength values decreased with pyrolytic carbon black addition.

Elastic modulus of those $\mathrm{MgO}-\mathrm{C}$ refractories obtained by the 3-point bending test are given in Figure 4 .

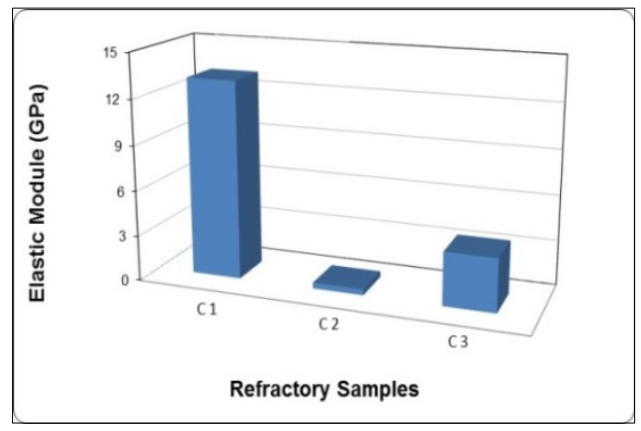

Figure 4. Elastic Modulus of MgO-C refractories obtained by 3-point bending test

While the elastic modulus values of the MgO-C materials including graphite were high, the elastic modulus values of the $\mathrm{MgO}-\mathrm{C}$ refractory compositions produced with the pyrolytic solid were lower. The highest elastic modulus value was reached in the $\mathrm{C} 1$ composition and the lowest elastic modulus was determined in the $\mathrm{C} 2$ material.

It is thought that the plate structure of graphite and therefore the void in the structure of the pyrolytic carbon black reduced the density of the refractories. The $\mathrm{C} 1$ refractory which had a higher packing density and higher strength values than other compositions was produced using graphite and resin. The $\mathrm{C} 1$ specimen had better bonding due to the larger surface area of flake graphite, together with good wetting of the resin entering between the flake graphite plates. As a result, higher energy was required to break those plates.

\subsection{The Results of Thermal Shock Test}

CCS (Figure 5) and 3-point bending test (Figure 6, 7) were applied to $\mathrm{MgO}-\mathrm{C}$ refractories after thermal shock test. Then for each specimen strength ratios, which means that how much its strength could be protected, were calculated by dividing those strengths by the strengths before thermal shock test (Figure 8,9).

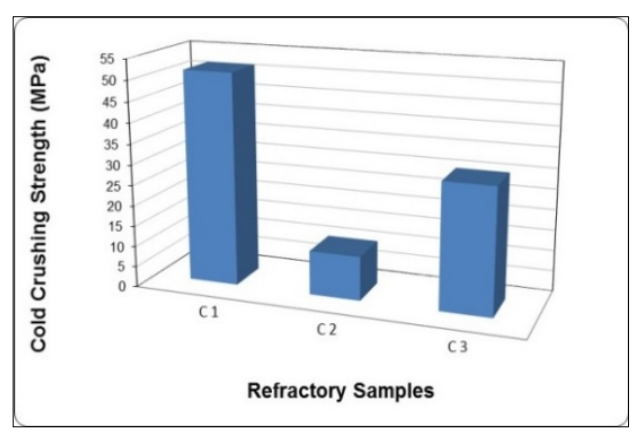

Figure 5. CCS of MgO-C refractories after thermal shock test

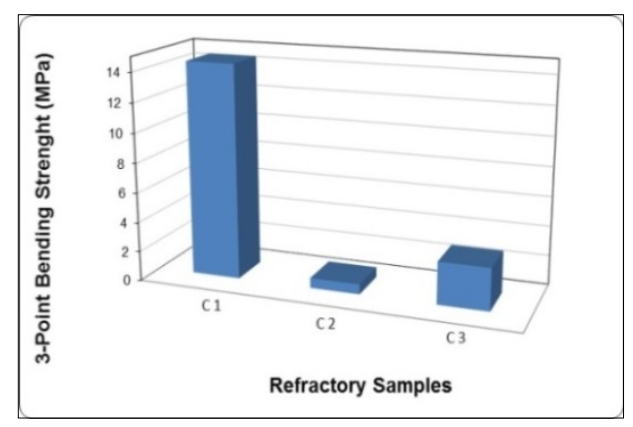

Figure 6. 3-point bending strength of $\mathrm{MgO}-\mathrm{C}$ refractories after thermal shock test

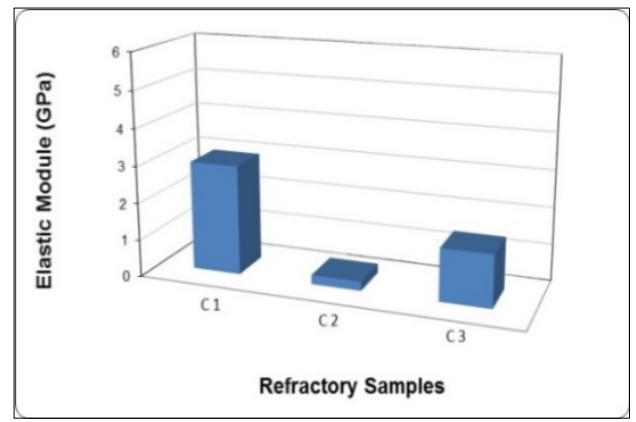

Figure 7. Elastic modulus of $\mathrm{MgO}-\mathrm{C}$ refractories after thermal shock test

The $\mathrm{C} 1$ composition produced by the resin and graphite among the $\mathrm{MgO}-\mathrm{C}$ refractory specimens subjected to the thermal shock test had the highest CCS, 3-point bending strength, and elastic modulus values as a result of both the compression and 3-point bending tests. It was observed that both strength values of all compositions decreased after thermal shock test. It is thought that pre-existing cracks and newly formed cracks after thermal shock reduced the strength values.

When the strength ratio values of MgO-C refractory materials in different compositions were examined (Figure $8,9)$, the $\mathrm{C} 1$ refractory material with the highest initial strength values either before or after thermal shock test at $1000^{\circ} \mathrm{C}$ maintained approximately $50 \%$ of its strength after thermal shock. Although the initial strength values were lower than the $\mathrm{C} 1$, it was observed that the $\mathrm{C} 2$ and the $\mathrm{C} 3$ refractories by incorporation of pyrolytic carbon black had generally higher strength ratio values.

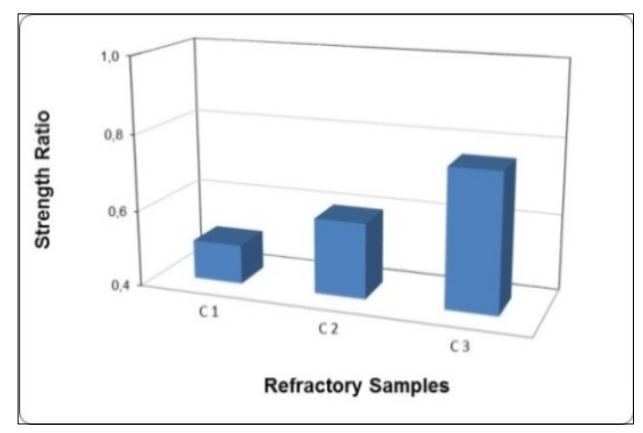

Figure 8. According to CCS test, the strength ratio values of thermally shocked $\mathrm{MgO}-\mathrm{C}$ refractories 


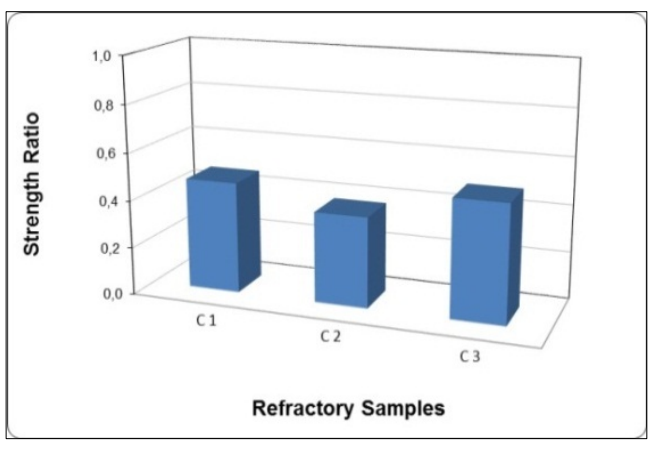

Figure 9. According to 3-point bending test, the strength ratio values of thermally shocked $\mathrm{MgO}-\mathrm{C}$ refractories

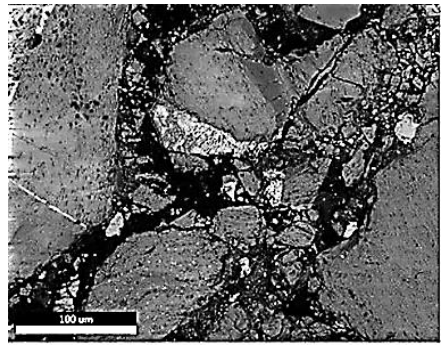

(a)

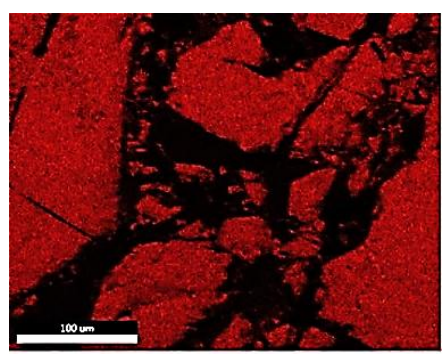

(d)

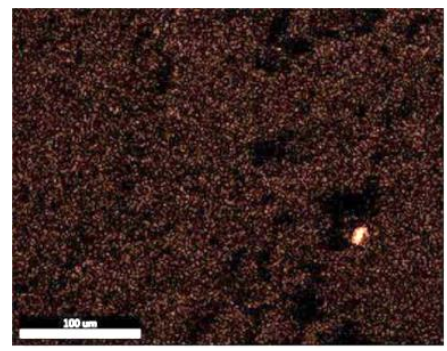

(g)

\subsection{Microstructure and Fracture Surface Characterizations}

According to microstructural image of the $\mathrm{C} 1$ refractory material produced by adding graphite and resin, graphite (dark gray) and $\mathrm{MgO}$ grains (gray) were well-bonded together, created a more dense structure than refractories produced by pyrolytic carbon addition. Black regions indicated porosities, and white regions indicated the compounds of $\mathrm{Al}, \mathrm{Si}$, and $\mathrm{Ca}$ coming as impurities in magnesia (Figure 10). 
In $\mathrm{C} 2$ refractory material produced by only pyrolytic carbon black as a carbon source had the highest amount of porosity, therefore the lowest density was reached in this material (Figure 11). In the $\mathrm{C} 3$ refractory material in which either flake graphite or pyrolytic carbon

black was used, number of porosities was higher than the $\mathrm{C} 1$ and lower than the $\mathrm{C} 2$ refractory materials (Figure 12).

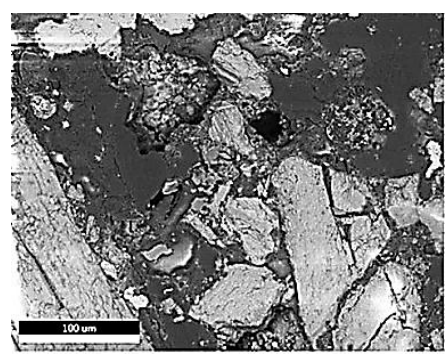

(a)

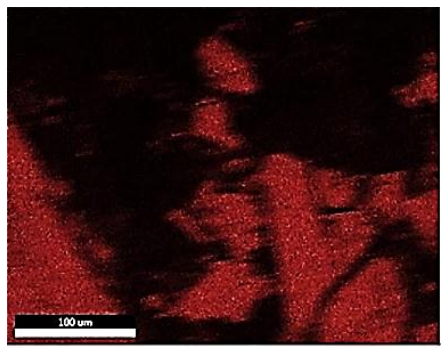

(d)

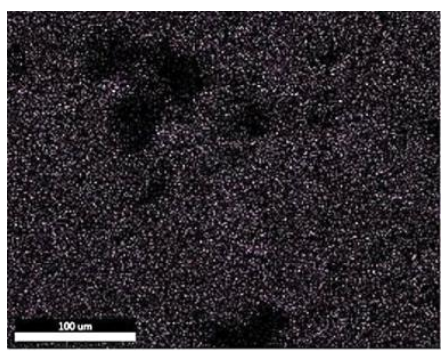

(g)

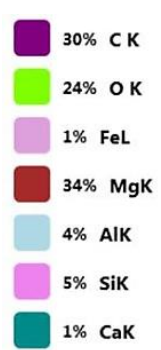

(b)

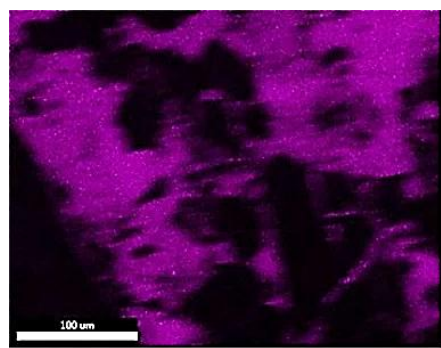

(e)

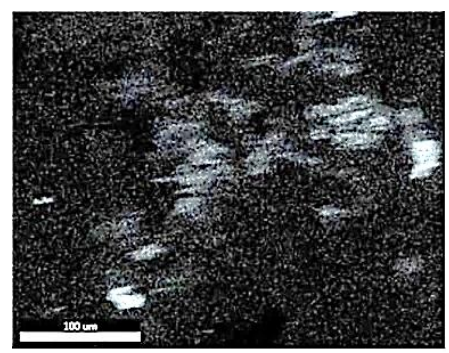

(h)

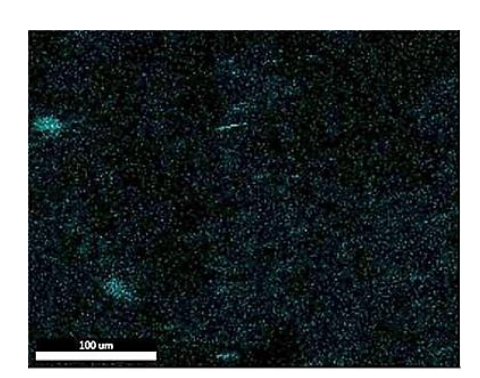

(j)

O K
MgK
AK
CK

According to the results of the EDX analysis (Figure 10-b, 11-b, and 12-b), it was observed that the amounts of $\mathrm{MgO}$ and $\mathrm{C}$ were high in the $\mathrm{C} 1$ sample. For the $\mathrm{C} 2$ and $\mathrm{C} 3$, the amount of carbon became to increase due to incorporation of pyrolytic carbon black. Moreover, the proportions of impurities in $\mathrm{MgO}$ such as $\mathrm{Si}, \mathrm{Al}$, and $\mathrm{Ca}$ increased while the amount of $\mathrm{MgO}$ decreased.

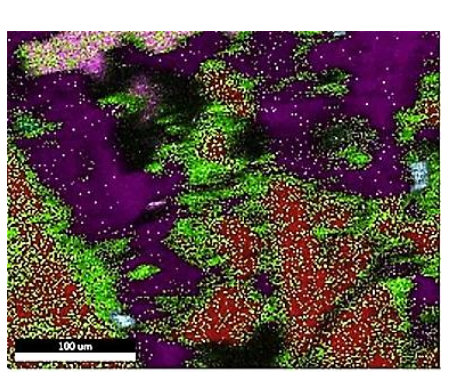

(c)

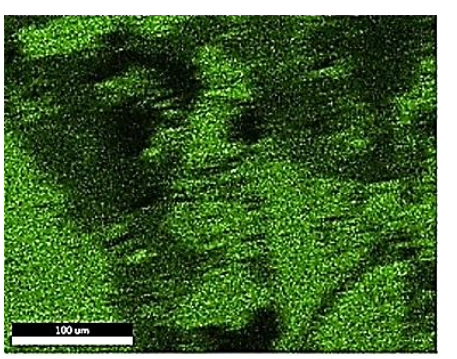

(f)

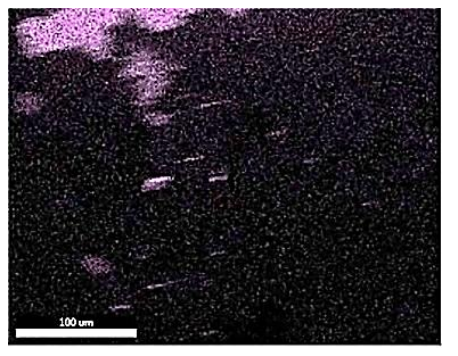

(i) 


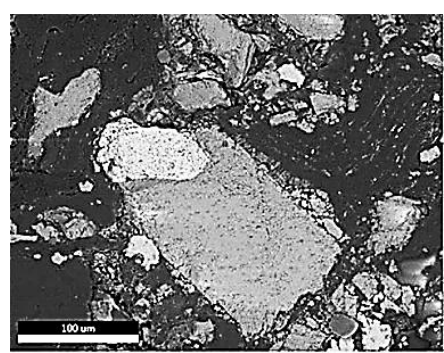

(a)

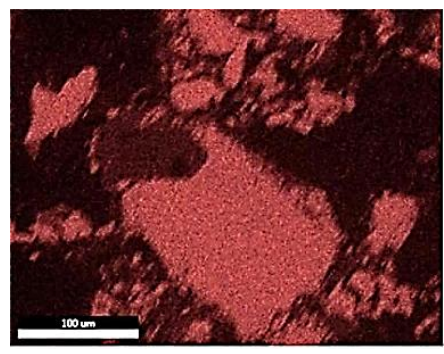

(d)

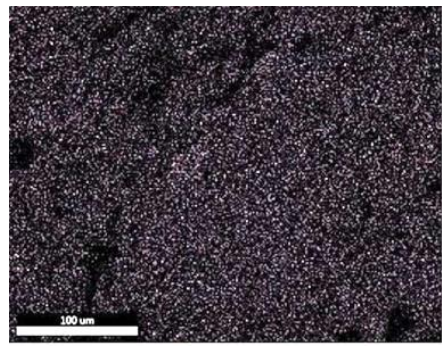

(g)

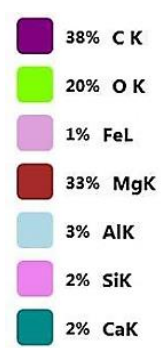

(b)

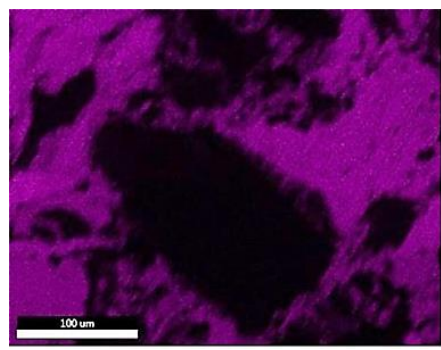

(e)

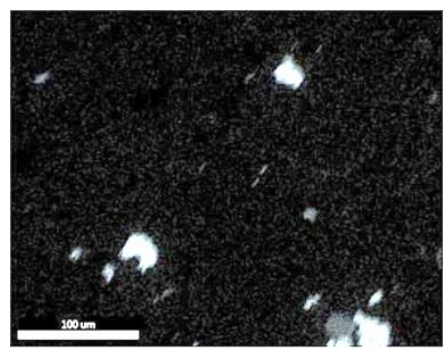

(h)

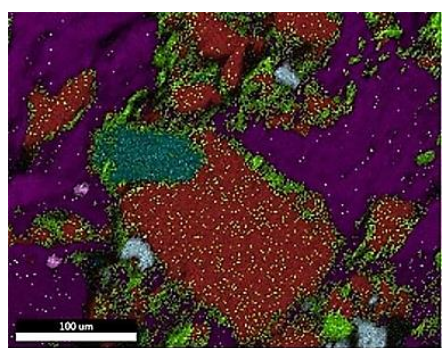

(c)

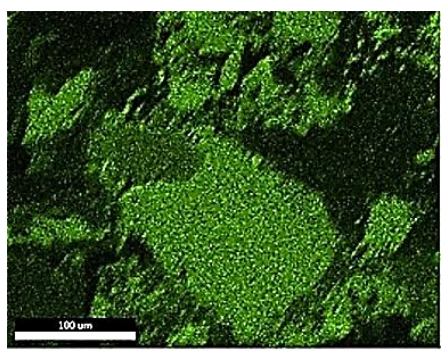

(f)

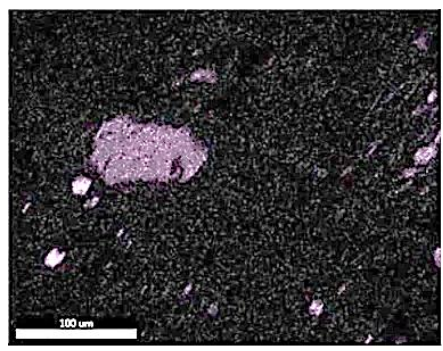

(i)

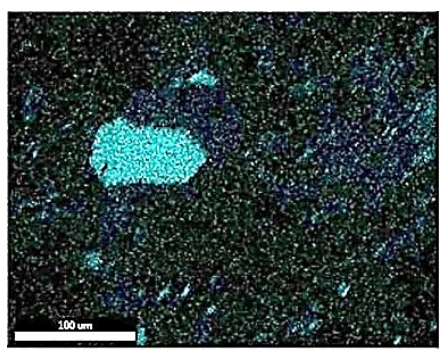

(j)

Figure 12. a) Microstructural image recorded with backscattered electrons (1000x), b) EDX analysis and c) colorized BSE image of R1 refractory material and the element distributions of $\mathrm{C} 3$ refractory material d) $\mathrm{Mg}$, e) $\mathrm{C}, \mathrm{f}$ ) $\mathrm{O}, \mathrm{g}$ ) $\mathrm{Fe}, \mathrm{h}$ ) $\mathrm{Al}$, i) $\mathrm{Si}$, and j) $\mathrm{Ca}$

According to the fracture surface images of the $\mathrm{C} 1$ refractory materials given in Figure 13, either before or after the thermal shock test, the $\mathrm{C} 1$ refractory material had predominantly transgranular and also intergranular cracks in its structure. Due to this type of fracture character, the C1 material had relatively high resistance to crack initiation while it had lower resistance to cracking propogation.

In the $\mathrm{C} 2$ and $\mathrm{C} 3$ materials, predominantly transgranular cracks were obtained before the thermal shock test (Figure 14, 15). After the thermal shock test, fracture type turned into either intergranular or transgranular crack types for the $\mathrm{C} 2$ and $\mathrm{C} 3$ refractories (Figure 14, 15).

The change in crack types as transgranular to either transgranular or intergranular types in the $\mathrm{C} 2$ and $\mathrm{C} 3$ refractory materials produced by incorporation of pyrolytic carbon black indicated higher strength ratios (Figure 8,9). The presence of porosities, intergranular fracture type as well as transgranular fracture, is considered to be an important factor affecting the change in mechanical properties obtained as a function of thermal shock at high temperature. 


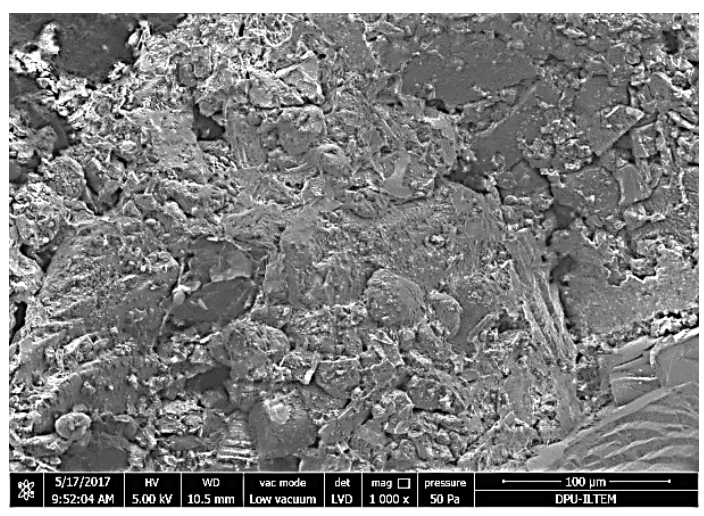

(a)

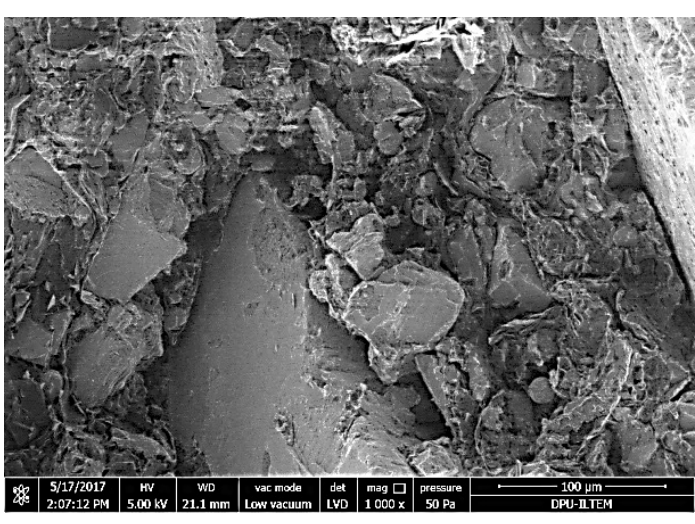

(b)

Figure 13. Fracture surface images of $\mathrm{C} 1$ recorded by secondary electrons (1000x): a) before, b) after thermal shock test

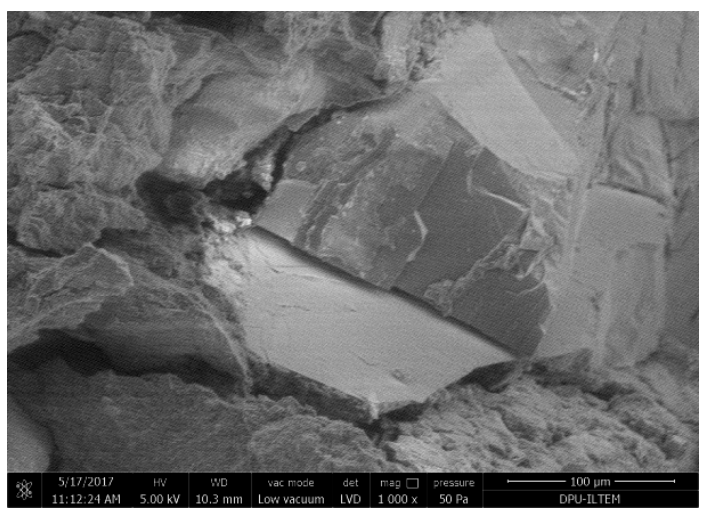

(a)

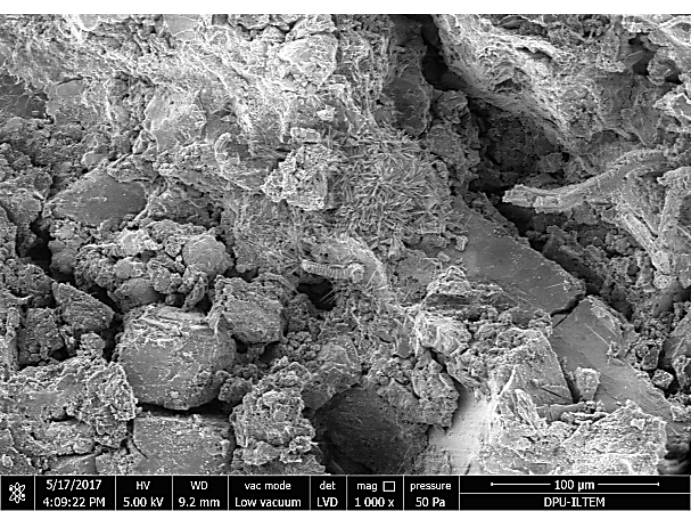

(b)

Figure 14. Fracture surface images of $\mathrm{C} 2$ recorded by secondary electrons (1000x): a) before, b) after thermal shock test

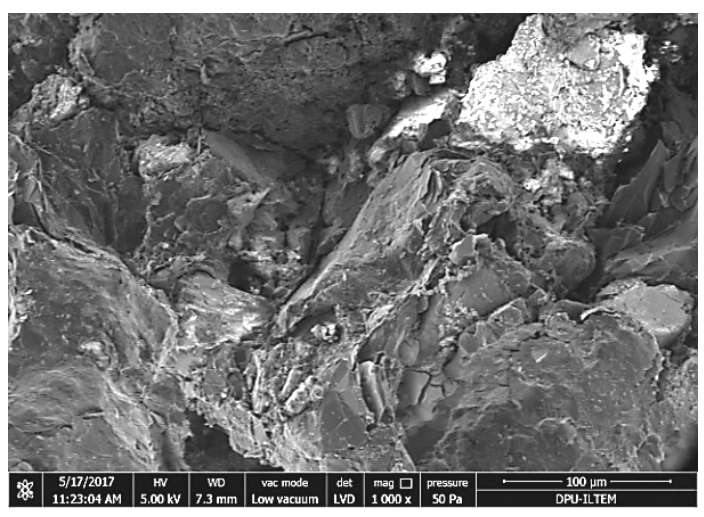

(a)

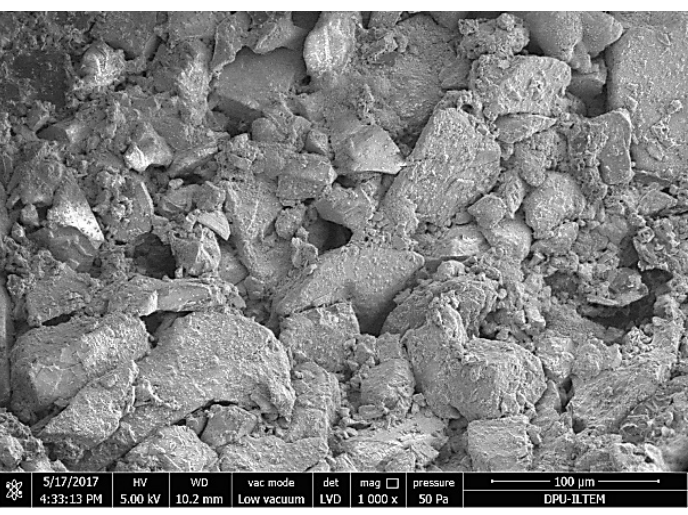

(b)

Figure 15. Fracture surface images of $\mathrm{C} 3$ recorded by secondary electrons (1000x): a) before, b) after thermal shock test 
Properties of the $\mathrm{MgO}-\mathrm{C}$ refractory samples either before or after the thermal shock test at $1000{ }^{\circ} \mathrm{C}$ are given in Table 2. The $\mathrm{C} 1$ had the highest density, CCS, bending strength, and elastic modulus values before and after thermal shock test.

Moreover, the $\mathrm{C} 1$ had the highest strength values obtained by either CCS or 3-point bending tests.

Table 2. Properties of $\mathrm{MgO}-\mathrm{C}$ refractory samples either before or after thermal shock test at $1000{ }^{\circ} \mathrm{C}$

\begin{tabular}{|c|c|c|c|c|}
\hline & \multirow{2}{*}{ Properties } & \multicolumn{3}{|c|}{ Compositions } \\
\hline & & $\mathrm{C} 1$ & $\mathrm{C} 2$ & $\mathrm{C} 3$ \\
\hline \multirow{5}{*}{$\begin{array}{l}\text { Before } \\
\text { Thermal } \\
\text { Shock }\end{array}$} & Density $\left(\mathrm{g} / \mathrm{cm}^{3}\right)$ & 2.89 & 2.43 & 2.74 \\
\hline & Porosity (\%) & 1.37 & 13.13 & 4.18 \\
\hline & $\mathrm{CCS}(\mathrm{MPa})$ & 102.5 & $1 ., 85$ & 39.99 \\
\hline & Elastic Modulus (GPa) & 13.12 & 0.38 & 3.52 \\
\hline & $\begin{array}{l}3 \text { Point Bending } \\
\text { Strenght (MPa) }\end{array}$ & 28.62 & 1.76 & 5.77 \\
\hline \multirow{5}{*}{$\begin{array}{c}\text { After } \\
\text { Thermal } \\
\text { Shock }\end{array}$} & Density $\left(\mathrm{g} / \mathrm{cm}^{3}\right)$ & 2.83 & 2.36 & 2.61 \\
\hline & Porosity (\%) & 7.23 & 19.83 & 14.32 \\
\hline & $\mathrm{CCS}(\mathrm{MPa})$ & 51.59 & 10.67 & 30.48 \\
\hline & Elastic Modulus (GPa) & 2.97 & 0.25 & 1.42 \\
\hline & $\begin{array}{l}3 \text { Point Bending } \\
\text { Strenght (MPa) }\end{array}$ & 14.48 & 0.67 & 2.86 \\
\hline \multicolumn{2}{|c|}{ CCS Strength Ratio (\%) } & 0.5 & 0.6 & 0.76 \\
\hline \multicolumn{2}{|c|}{3 Point Strength Ratio (\%) } & 0.47 & 0.38 & 0.5 \\
\hline
\end{tabular}

\section{Conclusions}

The $\mathrm{C} 1$ sample obtained by graphite and resin had the highest density, CCS, 3-point bending strength, and elastic modulus values. The density values began to decrease, and open porosities increased in the compositions by the pyrolytic carbon black addition. Before the thermal shock test, it was observed that CCS and 3-bending strength values increased as the open porosity values decreased, and thus strength was affected inversely by the porosity for all compositions. It was observed that both strength values of all compositions decreased after the thermal shock test. It was thought that pre-existing cracks and newly formed cracks after thermal shock reduced the strength values. The $\mathrm{C} 2$ and $\mathrm{C} 3$ refractories had a higher strength ratio due to the presence of either intergranular fracture or transgranular crack types after thermal shock test. Strength was also affected by the carbon source for all compositions.

\section{Acknowledgements}

This study was supported by TUBITAK under project no:
115M371. The author would like to thank Nesibe Sevde Ülvan who involved in this project for her support.

\section{REFERENCES}

[1] W. E. LEE, Refractories in Comprehensive Composite Materials, Ceramic, Carbon and Cement Matrix Composites, Vol 4, pp. 363-385, 2000.

[2] G.H. Cho, E. HeeKim, Y.G. Jung, Y.K. Byeun, Improving oxidation resistance and fracture strength of $\mathrm{MgO}-\mathrm{C}$ refractory material through precursor coating, Surface \& Coatings Technology, Vol 260, pp. 429-432, 2014.

[3] K. S. Lee, G.H. Jo, Y.G. Jung, Y. Byeun, Effect of carbon content on the mechanical behavior of $\mathrm{MgO}-\mathrm{C}$ refractories characterized by Hertzian indentation, Ceramics International, Vol 42, pp. 9955-9962, 2016.

[4] S. Mahato, S. K. Behera, Oxidation resistance and microstructural evolution in $\mathrm{MgO}-\mathrm{C}$ refractories with expanded graphite, Ceramics International, Vol 42, pp. 7611-7619, 2016.

[5] T. Zhu, Y. Li, S. Sang, Z. Xie, Improved thermal shock resistance of magnesia-graphite refractories by the addition of MgO-C pellets, Materials and Design, Vol 124, pp. 1623, 2017.

[6] G.H. Cho, E.H. Kım, J. LI, J.H. Lee, Y.Gi. Jung, Y.K. Byeun, C.Y. Jo, Improvement of oxidation resistance in graphite for $\mathrm{MgO}-\mathrm{C}$ refractory through surface modification, Trans. Nonferrous Met. Soc. China, Vol 24, pp. 119-124, 2014.

[7] H. Liu, F. Mengb, Q. Lib, Z. Huanga,, M. Fanga, Y.gaiLiua, X. Wua, Short communication Phase behavior analysis of $\mathrm{MgO}-\mathrm{C}$ refractory at high temperature: Influence of $\mathrm{Si}$ powder additives, Ceramics International, Vol 41, pp. 5186-5190, 2015.

[8] E. R. Benavidez, E. Brandaleze, Y. S. Lagorio, S. E. Gass, A. G. T. Martinez, Thermal and mechanical properties of commercial MgO-C bricks, RevistaMatéria, Vol. 20, pp. 571-5793, 2015.

[9] M. Banar, V. Akyıldız, A. Özkan, Z. Çokaygil, Ö. Onay, Characterization of pyrolytic oil obtained from pyrolysis of TDF (Tire Derived Fuel), Energy Conversion and Management, Vol 62, pp. 22-30, 2012.

[10] G. Lopeza, J. Alvareza, M. Amutioa, N.M. Mkhizeb, B. Danonb, P. van der Grypb, J.F. Görgensb, J. Bilbaoa, M. Olazara, Waste truck-tyre processing by flash pyrolysis in a conical spouted bed reactor, Energy Conversion and Management, Vol 142, pp. 523$532,2017$.

[11] A. Kebritchi, H. Firoozifar, K. Shams, A. Jalali-Arani, Effect of pre-devulcanization and temperature on physical and chemical properties of waste tire pyrolytic oil residue, Fuel, Vol 112, 319 325, 2013.

[12] Standard Test Methods for flexural strength of advanced ceramics at ambient temperature, In Annual Book of ASTM Standards, Designation: C1161-90, pp. 327-333, 1991. 